\title{
Technologies for utilization of industrial excess heat: Potentials for energy recovery and $\mathrm{CO} 2$ emission reduction
}

Sarah Broberg Viklund and Maria Johansson

\author{
Linköping University Post Print
}

\section{Tweet}

N.B.: When citing this work, cite the original article.

Original Publication:

Sarah Broberg Viklund and Maria Johansson, Technologies for utilization of industrial excess heat: Potentials for energy recovery and CO2 emission reduction, 2014, Energy Conversion and Management, (77), 369-379.

http://dx.doi.org/10.1016/j.enconman.2013.09.052

Copyright: Elsevier

http://www.elsevier.com/

Postprint available at: Linköping University Electronic Press

http://urn.kb.se/resolve?urn=urn:nbn:se:liu:diva-102611 


\title{
Technologies for utilization of industrial excess heat: Potentials for energy recovery and $\mathrm{CO}_{2}$ emission reduction
}

\author{
Sarah Broberg Viklund ${ }^{\mathrm{a}}$, Maria T. Johansson ${ }^{\text {a,b }}$ \\ ${ }^{a}$ Department of Management and Engineering, Division of Energy Systems, Linköping University, SE-58183 \\ Linköping, Sweden \\ ${ }^{\mathrm{b}}$ Department of Technology and Built Environment, Division of Energy and Mechanical Engineering, University \\ of Gävle, SE-80176 Gävle, Sweden \\ *Corresponding author. E-mail address: maria.johansson@liu.se, Fax: +46 13281788
}

\begin{abstract}
Industrial excess heat is a large untapped resource, for which there is potential for external use, which would create benefits for industry and society. Use of excess heat can provide a way to reduce the use of primary energy and to contribute to global $\mathrm{CO}_{2}$ mitigation. The aim of this paper is to present different measures for the recovery and utilization of industrial excess heat and to investigate how the development of the future energy market can affect which heat utilization measure would contribute the most to global $\mathrm{CO}_{2}$ emissions mitigation. Excess heat recovery is put into a context by applying some of the excess heat recovery measures to the untapped excess heat potential in Gävleborg County in Sweden. Two different cases for excess heat recovery are studied: heat delivery to a district heating system and heat-driven electricity generation. To investigate the impact of excess heat recovery on global $\mathrm{CO}_{2}$ emissions, six consistent future energy market scenarios were used. Approximately $0.8 \mathrm{TWh} /$ year of industrial excess heat in Gävleborg County is not used today. The results show that with the proposed recovery measures approximately $91 \mathrm{GWh} /$ year of district heating, or $25 \mathrm{GWh} /$ year of electricity, could be supplied from this heat. Electricity generation would result in reduced global $\mathrm{CO}_{2}$ emissions in all of the analyzed scenarios, while heat delivery to a DH system based on combined heat and power production from biomass would result in increased global $\mathrm{CO}_{2}$ emissions when the $\mathrm{CO}_{2}$ emission charge is low.
\end{abstract}

Keywords: Industrial excess heat, Heat recovery, Electricity generation, District heating, $\mathrm{CO}_{2}$ emission, Energy market scenarios

$\begin{array}{ll}\text { Abbreviations } \\ \text { Bio-CHP } & \text { Bio combined heat and power } \\ \text { CHP } & \text { Combined heat and power } \\ \text { COP } & \text { Coefficient of performance } \\ \text { DC } & \text { District cooling } \\ \text { DH } & \text { District heating } \\ \text { EED } & \text { Energy Efficiency Directive } \\ \text { EMS } & \text { Energy market scenarios } \\ \text { ENPAC } & \text { Energy Price and Carbon Balance Scenarios } \\ \text { EU } & \text { European Union } \\ \text { FT } & \text { Fischer Tropsch } \\ \text { GHG } & \text { Greenhouse gases } \\ \text { HOB } & \text { Heat-only boiler } \\ \text { IS } & \text { Industrial symbiosis } \\ \text { LiBr } & \text { Lithium bromide } \\ \text { NGCC } & \text { Natural gas combined cycle }\end{array}$




$\begin{array}{ll}\text { ORC } & \text { Organic Rankine cycle } \\ \text { PCM } & \text { Phase change material } \\ \text { PV } & \text { Photovoltaic } \\ \text { TEG } & \text { Thermoelectric generator } \\ \text { TPV } & \text { Thermophotovoltaic }\end{array}$

\section{Introduction}

In recent years, the unsustainable use of the world's resources has gained increased attention. Efficient use of resources can reduce the use of primary energy and thus reduce emissions of anthropogenic greenhouse gases (GHG). In its work against climate change, the European Union (EU) has promoted the importance of energy efficiency measures to reduce the use of primary energy and set a goal to increase energy efficiency by $20 \%$ compared to 1990 levels [1]. The Energy Efficiency Directive (EED) stresses the use of industrial excess heat as a way to reach the EU target [2]. There is no clear definition of what can be considered as excess heat. Several definitions have been proposed such as "heat that is left over after an industrial process has become (thermodynamically) optimized" or "excess heat that cannot be used directly in the industrial process" [3]. The definition of industrial excess heat that will be used in this paper is as follows: Industrial excess heat is heat generated as a by-product of industrial processes. This heat is not used today, but could be used to create benefits for the industry and the society.

\section{Aim and delimitations}

The aim of this paper is to map and investigate different options for the recovery and use of industrial excess heat. The study does not claim to review the whole market of heat recovery technologies; however, the paper will show the diversity and complexity of the technologies that might be used for industrial excess heat recovery and will classify them according to purpose. The paper will put the use of excess heat into a context by applying some of the measures to the untapped excess heat potential in Gävleborg County and will report the energy recovery potentials and global $\mathrm{CO}_{2}$ emission reductions. The paper also aims to investigate how different future energy markets affect global $\mathrm{CO}_{2}$ emissions related to the implementation of different heat recovery options. The objective of the analysis is to provide information that can be used as a decision basis, e.g., by industry when considering investment in heat recovery equipment, and by policymakers evaluating different strategies for climate change mitigation.

Excess heat can be used in-house and transferred to other facilities. The focus of this paper is on recovery measures for external use of industrial excess heat. The recovery potentials are not put in a geographical context; distances between the heat source and potential users were not considered. Further, this study does not investigate industrial excess energy in the form of combustible waste gases or by-products.

\section{Industrial excess heat}

Efficient use of energy can take the form of improvements in a single production process as well as improvements in a larger system where the energy flows in the system are connected and thermodynamically and/or economically optimized. Several options are available for the use of industrial excess heat. An important first step is reduction of the amount of excess heat 
released by the production processes. If the available heat can be used in the industrial process in which it arose, this is, in most cases, the best choice and often a relatively inexpensive and easy way to use the heat. This recycling of heat can be achieved by heat exchange, for example, by preheating of incoming air, water, or material. Recovery of the heat for external use is another possible use. As it may lead to heat losses, the recovery process must be located close to the heat source and/or maintain a high efficiency in heat transfer. The heat can also be used to generate electricity, which could be used internally or externally.

The use of excess heat may result in several savings. Not only may the primary energy demand decrease, but $\mathrm{CO}_{2}$ emissions may also be reduced and economic gains realized [4]. Industrial excess heat characteristics determine the feasibility of recovering the heat. Quantity and quality are two important parameters: quantity describes the amount of energy contained in the heat streams, while quality measures the usefulness of the stream and is determined by the temperature [5].

The use of available industrial excess heat has been studied e.g., [6-9], but it is argued that a large untapped potential exists [10,11]. The energy efficiency target and the possibility of the use of industrial excess heat resulting in environmental and economic gains [4] has drawn attention to the importance of recovery of excess heat and the development and implementation of recovery technologies.

\section{Gävleborg County}

This study applied measures for the recovery and utilization of industrial excess heat to an industrial area and calculated the energy recovery potential and effects on global $\mathrm{CO}_{2}$ emissions. The industrial area considered in the paper is Gävleborg County, which is located in central Sweden on the Baltic Sea coast and is Sweden's tenth most populated county (out of 21 counties) [12]. The county's business activity is diversified, but it has a large share of energy-intensive industry (e.g., pulp and paper and steel industries) and this study focuses on these industries. The annual use of energy (2010) within the county's industry sector is approximately $11.2^{1}$ TWh. This corresponds to about $6.7 \%$ of energy use in this sector in Sweden [13]. The annual use of district heating (DH) in the county sums to approximately 2 TWh [13], of which approximately $11 \%$ originates from industrial excess heat [14].

\section{Methodology}

\subsection{Questionnaire}

Approximately $67 \%{ }^{2}$ of Gävleborg County's energy end-use in 2008 was used within the industrial sector [13]. Due to the complexity of the energy flows in energy-intensive industries, a questionnaire rather than an energy audit was used by the authors to gather information. This enabled firms to contribute their own data regarding energy flows and, at the same time, allowed for a larger sample than would be possible with energy audits.

\footnotetext{
${ }^{1}$ This includes electricity use in the construction sector.

${ }^{2}$ The county's total energy end-use does not include electricity use within the transportation sector.
} 
A web-based questionnaire was sent to 58 industrial firms within different industrial sectors in the spring of 2012. The list of respondents was obtained from the County Administrative Board of Gävleborg. All the firms are classified as firms holding a high environmental impact [15]. The questionnaire focused on excess heat quantity and quality (temperatures of the heat flows and flow rates of the excess heat flows) in different energy carriers at the firms and the potential for heat recovery (internally and externally). The questionnaire was answered by the person in charge of energy issues at the firm, who was either the energy manager or the production manager, and the response rate of the study was approximately $33 \%$.

\section{$5.2 \mathrm{CO}_{2}$ emission evaluation}

To handle the uncertainty regarding the future energy market and to evaluate the effects of heat recovery on global $\mathrm{CO}_{2}$ emissions, different scenarios predicting future energy markets for 2030 were used. By using consistent energy market scenarios (EMS) that predict possible cornerstones of the future energy market, more robust results can be obtained. To obtain a consistent scenario, it is important that the energy market parameters are correlated to each other. In this study, the Energy Price and Carbon Balance Scenarios (ENPAC) tool was used. A more thorough description of the tool can be found in Axelsson \& Harvey [16] and Axelsson et al. [17]. Inputs to the tool were prices of fossil fuel and charges for emitting $\mathrm{CO}_{2}$. Input prices were taken from the scenarios presented in World Energy Outlook 2011 [18]. In the evaluation of the effects on global $\mathrm{CO}_{2}$ emissions, biomass was considered a limited resource on the market, and a marginal electricity system was assumed. Based on the inputs to the ENPAC tool, the marginal technology for electricity production (build margin) and the marginal user of biomass were determined. Moreover, two potential DH systems were considered: a small Swedish system based on bio heat-only boilers (bio-HOB) and a large Swedish system based on bio combined heat and power (bio-CHP).

When electricity is produced from excess heat, the marginal electricity approach results in the marginal electricity producer reducing its electricity production by an equal amount, which affects the global $\mathrm{CO}_{2}$ emissions. When excess heat replaces energy originating from biomass use, biomass will be available and can be used by the marginal user of biomass. The ENPAC tool could choose between two marginal users of biomass: a coal power plant with co-firing of biomass or a producer of the biofuel Fischer Tropsch (FT) diesel. The resulting impact on global $\mathrm{CO}_{2}$ emissions if industrial excess heat is utilized can be seen in Table 1.

Table 1. Energy market scenarios data for 2030. Negative values for the $\mathrm{CO}_{2}$ emissions correspond to increased emissions.

\begin{tabular}{lllllll}
\hline Energy market scenario & $\mathbf{1}^{\mathbf{a}}$ & $\mathbf{2}^{\mathbf{b}}$ & $\mathbf{3}^{\mathbf{c}}$ & $\mathbf{4}^{\mathbf{a}}$ & $\mathbf{5}^{\mathbf{b}}$ & $\mathbf{6}^{\mathbf{c}}$ \\
\hline $\begin{array}{l}\text { Fossil fuel price level } \\
\mathrm{CO}_{2} \text { emission charge }\end{array}$ & $\begin{array}{l}\text { High } \\
\text { Low }\end{array}$ & $\begin{array}{l}\text { Low } \\
\text { Low }\end{array}$ & $\begin{array}{l}\text { Low } \\
\text { High }\end{array}$ & $\begin{array}{l}\text { High } \\
\text { Low }\end{array}$ & $\begin{array}{l}\text { Low } \\
\text { Low }\end{array}$ & $\begin{array}{l}\text { Low } \\
\text { High }\end{array}$ \\
\hline Marginal user of biofuel & FT & FT & Coal & FT & FT & Coal \\
$\begin{array}{l}\mathrm{CO}_{2} \text { reduction from marginal use of biomass } \\
(\mathrm{kg} \mathrm{CO} / \mathrm{MWh} \text { fuel })\end{array}$ & 118 & 118 & 356 & 118 & 118 & 356 \\
$\begin{array}{l}\text { Build margin technology for electricity } \\
\text { production }\end{array}$ & Coal & Coal & NGCC & Coal & Coal & NGCC \\
$\begin{array}{l}\mathrm{CO}_{2} \text { emissions from marginal production of } \\
\text { electricity }\left(\mathrm{kg} \mathrm{CO}_{2} / \mathrm{MWh}_{\mathrm{el}}\right)\end{array}$ & 714 & 714 & 340 & 714 & 714 & 340
\end{tabular}




$\begin{array}{lllllll}\text { DH system } & \begin{array}{l}\text { Bio- } \\ \text { HOB }\end{array} & \begin{array}{l}\text { Bio- } \\ \text { HOB }\end{array} & \text { Bio-HOB } & \begin{array}{l}\text { Bio- } \\ \text { CHP }\end{array} & \text { Bio-CHP } & \text { Bio-CHP } \\ \mathrm{CO}_{2} \text { reduction if industrial excess heat is } \\ \text { exported to a } \mathrm{DH} \text { system }\left(\mathrm{kg} \mathrm{CO} / \mathrm{MWh}_{\text {heat }}\right)\end{array}$

\footnotetext{
${ }^{a}$ Fuel prices on the world market: Oil 63 EUR/MWh, Natural gas 36 EUR/MWh, Coal 12 EUR/MWh, $\mathrm{CO}_{2}$ emission charge 30 EUR/tonne. Derived from the "Current policies scenario" in World Energy Outlook 2011 [18].

${ }^{\mathrm{b}}$ Fuel prices on the world market: Oil $55 \mathrm{EUR} / \mathrm{MWh}$, Natural gas $34 \mathrm{EUR} / \mathrm{MWh}$, Coal $11 \mathrm{EUR} / \mathrm{MWh}, \mathrm{CO}_{2}$ emission charge 30 EUR/tonne. Derived from the "New policies scenario" in World Energy Outlook 2011 [18].

${ }^{\mathrm{c}}$ Fuel prices on the world market: Oil $46 \mathrm{EUR} / \mathrm{MWh}$, Natural gas $28 \mathrm{EUR} / \mathrm{MWh}$, Coal 7 EUR/MWh, $\mathrm{CO}_{2}$ emission charge 72 EUR/tonne. Derived from the "450 scenario" in World Energy Outlook 2011 [18].
}

\section{Excess heat potential in Gävleborg County}

Energy use by the firms that completed the questionnaire totalled approximately 9.5 $\mathrm{TWh} /$ year. The firms accounted for approximately $62 \%$ of the annual use of energy within the industrial sector in Gävleborg County. The study shows that several firms hold untapped excess heat potentials. Among the firms that completed the questionnaire, $74 \%$ declared that they had excess heat, although only $50 \%$ of them reported specific values on the untapped heat potential. The firms that specified their heat potentials accounted for more than $91 \%$ of the total energy use among the firms that reported heat potentials.

Fig. 1 illustrates the untapped excess heat potential from the firms studied. In some cases, the firms assigned the total potential, and in some cases the potential was calculated based on the flows and temperatures specified by the firms. No excess energy flows were aggregated by the authors in the calculations of heat potentials (see Fig. 1). However, energy flows may have been aggregated at firm level by the company representatives answering the questionnaire. The excess heat potential for each temperature level and heat carrier can be seen in Fig. 1, and the results show that the largest heat potential is carried in water. 


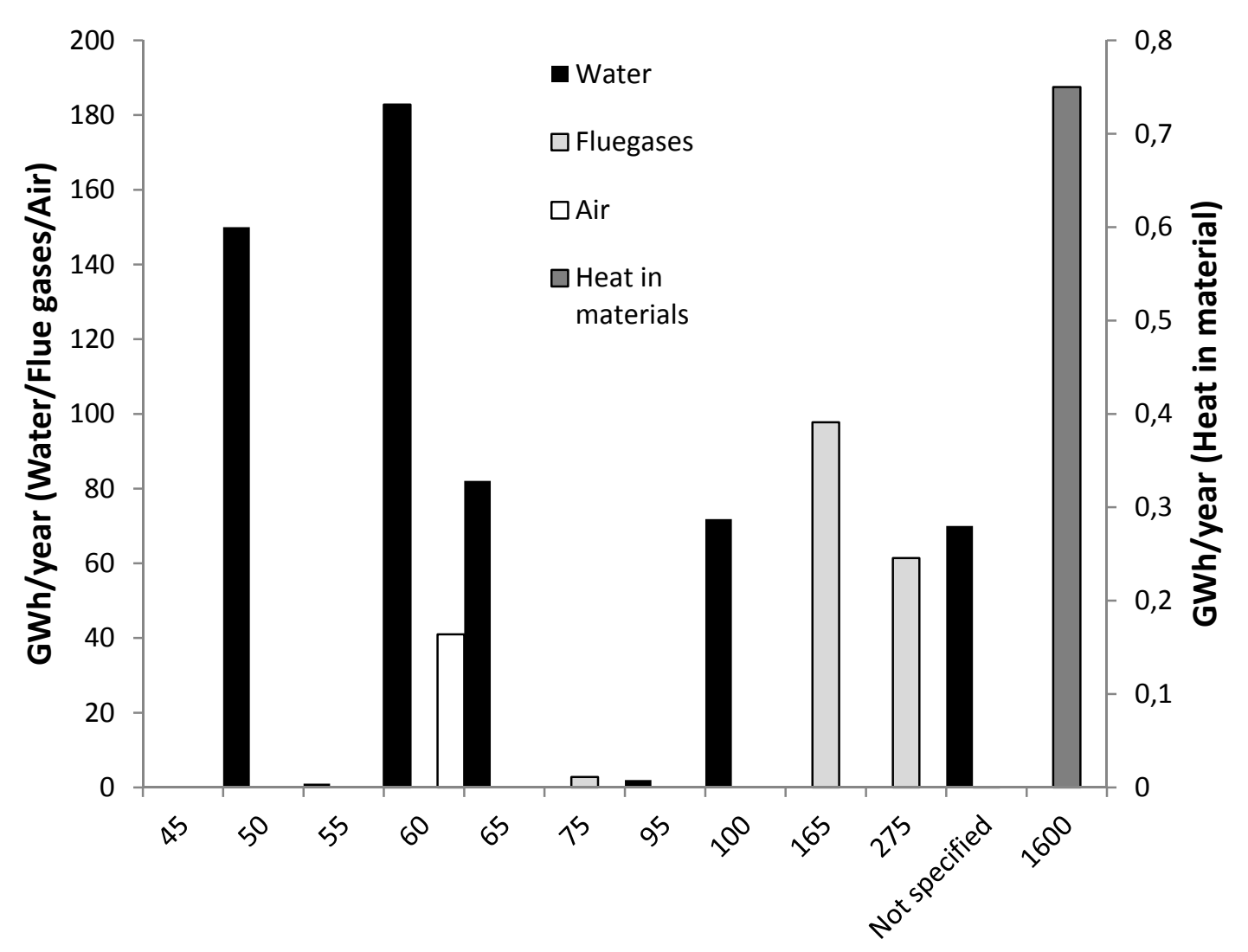

Temperature $\left({ }^{\circ} \mathrm{C}\right)$

Fig. 1. Industrial excess heat potential in Gävleborg County associated with different temperature levels and energy carriers. ${ }^{3}$

The temperature levels in water are lower than in flue gases, ranging from $50^{\circ} \mathrm{C}$ to $100^{\circ} \mathrm{C}$ compared to $75^{\circ} \mathrm{C}$ to $275^{\circ} \mathrm{C}$. The highest temperatures can be found as heat carried in materials, but the potential is lower than for the other heat carriers. The total excess heat potential reported by the firms answering the questionnaire totalled approximately 0.8 $\mathrm{TWh} /$ year. This potential represents $8.4 \%$ of the energy use among the firms that completed the questionnaire and $5.2 \%$ of the energy use in the industrial sector.

\section{Heat recovery}

In this study, excess heat recovery options have been classified based on their purpose. The classifications are heat harvesting, heat storage, heat utilization, and heat conversion.

\subsection{Heat harvesting}

Heat-harvesting technologies were included in the study because they are a part of the recovery chain both for internal and external use. In addition, they can be used to make the heat accessible for excess heat recovery. This section will briefly present heat exchangers, radiation collectors, and heat pumps.

\footnotetext{
${ }^{3}$ Some excess heat potentials are (or are almost) rounded to zero in the graph. The potential in water $\left(55^{\circ} \mathrm{C}\right)$ is 1 $\mathrm{GWh}$ /year; in water $\left(95^{\circ} \mathrm{C}\right)$ it is $2 \mathrm{GWh} /$ year; in flue gases $\left(75^{\circ} \mathrm{C}\right)$ it is $2.8 \mathrm{GWh} /$ year; in flue gases (not specified) it is approximately $0.1 \mathrm{GWh} /$ year; and in air $\left(45^{\circ} \mathrm{C}\right)$ it is is $1 \mathrm{MWh} /$ year.
} 
Heat exchangers are used to exchange heat between two moving media (gases or liquids) and offer the option to transfer heat from heat sources with corrosive or toxic natures to a clean medium, for example, from exhaust gases to pure water. Transferring heat between gas and liquid also offers possibilities to use the heat for applications that demand the heat source be in liquid form, such as $\mathrm{DH}$ systems or certain electricity generation technologies. Heat exchangers are commercially available; to meet a variety of application demands, different configurations of heat exchangers have been designed (e.g., double pipe heat exchanger, shell-and-tube heat exchanger, condensers, plate and frame heat exchanger) [19].

In solar thermal applications, solar radiation is absorbed by a collector as heat and transferred to a working medium such as water, oil, or air [20]. This technology can be used to capture heat radiation from hot materials but has not commonly been used for industrial applications. However, solar collectors may not be the best choice for recovery of heat radiation; they are designed to have a relatively low absorptivity in the wavelength spectrum associated with the heat radiation from hot material [21]. Therefore, an array of water-filled copper pipes could be a more efficient heat collector for industrial excess heat recovery. In a study by Nilsson [22], heat was recovered from cooling beds at a steel plant where steel cooled from $1000^{\circ} \mathrm{C}$ to $300^{\circ} \mathrm{C}$. The study investigated different configurations of radiation collectors such as commercial solar collectors and panels made of water-filled copper pipes. The collectors were installed above the cooling beds, and the results showed that it was possible to recover more radiation with the copper pipes than with the solar collectors. With feasible installations, $20-25 \%$ of the heat in steel could be recovered and transferred to water.

A heat pump can be used to transfer heat from a heat source to a heat sink by transferring heat from a low-temperature medium to a high-temperature medium. Heat pumps are commercially available and provide a way to use low-temperature industrial excess heat in applications that require higher temperatures [23]. The coefficient of performance (COP) describes the relationship between the energy input and output. The COP value is in theory greater than one but may in practice fall below one because of heat losses. Common COP values for heat pumps are 2-3 [19]. Several types of commercial heat pumps based on different technologies are available, and new heat pump technologies are under development to increase energy efficiency, for example [23].

\subsection{Heat storage}

Intermittent excess heat flows may obstruct utilization of excess heat. Heat storage technologies can be used to store the energy for later use or even to transport it to external users. There are three different storage mechanisms: sensible heat storage, latent heat storage, and chemical heat storage $[20,24]$.

In sensible heat storage, the temperature of the heat storage material is elevated when heat is stored. There are both liquid and solid sensible heat storage materials, including oils, inorganic molten salts, and sand-rock materials [20]. A simple system for sensible heat storage is a storage tank with water. Sensible heat storage is the cheapest and most developed technology, but it also has the lowest heat storage capacity.

In latent heat storage, a Phase Change Material (PCM) stores/releases heat during melting/solidification or gasification/liquefaction. Latent heat storage has a higher heat storage density than sensible heat storage, and the temperature of the PCM does not significantly change when heat is absorbed or released because the heat is used in the phase change process. One drawback is the low thermal conductivity of most PCMs, which requires large heat exchanger surfaces. Two commercial PCMs are inorganic salts and paraffin. $[20,24-27]$ 
In chemical heat storage, heat is stored as chemical energy through endothermal reactions and can be released in the reverse exothermal reaction. Two materials used for chemical heat storage are ammonia and hydroxides. Chemical heat storage is the technology with the highest heat storage density. [20] Sensible heat storage is a proven technology, but latent heat storage and chemical heat storage are technologies under research.

\subsection{Heat utilization}

Heat utilization technologies can be used in various energy systems, such as DH, district cooling (DC), and other heat cooperations, for recovery of excess heat without a need to convert the heat to another form of energy.

\subsubsection{District heating}

DH is used to supply buildings or industries with heat from a collective heating system. The thermal energy can be obtained from different sources, such as combustion of different fuels in boilers and industrial excess heat $[28,29]$. In recent years, the amount of industrial excess heat delivered to DH systems has increased in Sweden ${ }^{4}$ [14]. The heat is transferred to customers in grid piping systems and the thermal energy is carried in either hot water or steam. DH systems often use hot water as a medium because the use of steam results in greater heat losses. After heat distribution, the water returns to the heat source, where it is reheated. [28]

The water temperature in the DH system depends on the heat load demand. In Sweden, the supply temperature in hot water $\mathrm{DH}$ systems varies between $70^{\circ} \mathrm{C}$ in summer and $120^{\circ} \mathrm{C}$ in winter. The corresponding temperatures for return water are $40^{\circ} \mathrm{C}$ and $65^{\circ} \mathrm{C}$. [28,30] The supply temperature varies in different parts of the world, partly due to diverse piping systems. Steam-based systems have a supply temperature of $150^{\circ} \mathrm{C}$ to $300^{\circ} \mathrm{C}$ [31]. In recent years, increased attention has been given to low-temperature heating systems used to distribute heat at industrial plants and the development of low-temperature $\mathrm{DH}$ systems, with a supply temperature down to $50^{\circ} \mathrm{C}$ [32]. Depending on the temperature level of the excess heat, the energy can be fed directly to the DH grid or must first be upgraded. Low-temperature excess heat may be used in hot water DH systems following thermal upgrading, which can be accomplished with heat pumps [31,33].

\subsubsection{District cooling}

In a DC system, water is cooled in a central facility and then distributed to costumers. Industrial excess heat can be used in the cooling process through absorption cooling. In contrast to compression chilling, the process is not driven with electricity but a heat-driven cooling process $[34,35]$. Absorption cooling has a minor electricity demand of approximately $2 \%$ of the produced cooling for pumping the coolant [36]. Absorption cooling is suitable for water-distributed cooling, and absorption chillers are commercially available for large-scale use with the working medium lithium bromide $(\mathrm{LiBr}) /$ water; customized solutions exist for small-scale use [34]. The working medium determines the performance of the cooling system, and $\mathrm{LiBr} /$ water and ammonia/water are the most common working mediums [37]. Reported COP for heat-driven absorption chillers ranges between 0.5 and 0.8 [34,36,37]. COP depends, for example, on the temperature of the heat delivered to the absorption chiller: higher temperature gives a higher COP.

The absorption cooling process can be described as follows: Return water from the DC system is cooled in the evaporator when the refrigerant (usually water) is evaporated under low pressure. The cooled DC water is distributed in the DC system, and the evaporated

\footnotetext{
${ }^{4}$ Based on figures from 2006-2010, except for 2009, where the deliveries decreased.
} 
refrigerant is transferred to the absorber, where it is absorbed by the working medium (e.g. $\mathrm{LiBr}$ ). The $\mathrm{LiBr}$ solution is pumped to the generator, where the concentration is increased because the water evaporates as a result of heat supply (e.g., industrial excess heat). The concentrated $\mathrm{LiBr}$ is transferred back to the absorber, and the steam is condensed in the condenser. The liquid water is transferred back to the evaporator, closing the cycle. [34,38]

\subsubsection{Heat cooperation}

Industrial excess heat can be recovered and reused through cooperation between different actors. Industrial symbiosis (IS) or cluster collaborations are exchanges of resources, such as heat between industries which result in competitive advantages [39]. The best-known example of cluster collaboration and reuse of energy is the Eco-Industrial Park at Kalundborg in Denmark, where excess heat in the form of steam is exchanged between the companies [40].

Several studies have focused on advantages related to synergies. Wolf et al. [41] evaluated obstacles and success factors for biofuel combines; they concluded that excess heat exchange is one of the main drivers for collaboration. Martin and Eklund [39] studied how the environmental performance of first generation biofuels can be improved through IS. Because biogas and biodiesel production processes require low temperatures, excess heat from an ethanol production plant could be used in these processes. Ellersdorfer and Weiss [42] studied the synergy effects of cooperation between a biogas production plant and a cement plant in which the excess heat from the cement plant was used in the biogas production process, and the biogas replaced fossil fuels in the cement plant, showing significant $\mathrm{CO}_{2}$ emission savings. Combustion of biomass (e.g., boiler efficiency) is affected by the moisture content of biomass. Industrial excess heat could be used to reduce the primary energy use of the energyintensive pre-treatment step in which the biomass is dried. Li et al. [43] investigated the use of low-grade excess heat in the form of flue gases and hot water for biomass drying. Other studies have highlighted the use of excess heat in greenhouses $[44,45]$ and algae cultivations [46]. Fahlén et al. [47] investigated the integration of heat-driven cooling in the DH system to raise the heat demand during low heat demand periods. The study showed that the integration of absorption cooling in the DH system has a potential for increasing the utilization of excess heat and leads to cost-effective $\mathrm{CO}_{2}$ emission reduction.

\subsection{Heat conversion}

Heat conversion technologies can be used to convert thermal energy into electricity.

\subsubsection{Rankine cycle}

In the Rankine cycle, heat is converted into electricity. A liquid working medium is pressurized and pumped into an evaporator, where it is heated and evaporated. This gaseous working medium expands in a turbine to generate electricity in a generator. The steam is then cooled in a condenser before being pumped back to the evaporator, closing the loop when evaporated again. The traditional steam Rankine cycle uses water as working medium, which makes it suitable only for heat sources with temperatures higher than $240-370^{\circ} \mathrm{C}$. [48-50] At lower temperatures, the traditional steam Rankine cycle is not cost-effective because the lowpressure steam requires larger equipment. In addition, the energy content of low-temperature excess heat may not be sufficient to superheat the steam, which must be done to prevent steam condensation and erosion of the turbine blades [49].

Some Rankine cycles use working mediums with lower boiling points than water, for example the organic Rankine cycle (ORC) and the Kalina cycle. The ORC uses an organic fluid as working medium, and working mediums with a range of boiling points are available. It is important to choose the working medium best suited for the specific heat source because the performance of the ORC system is highly dependent on the characteristics of the working 
medium [51-53]. Organic working fluids rather than water have been shown to increase the output of useful work when recovering low temperature excess heat [54]. The Kalina cycle uses a mixture of water and ammonia as its working medium, and the proportions of the two fluids determine the boiling point. Both the ORC and the Kalina cycles can be optimized by choosing a working medium with a boiling point that matches the temperature of the heat source. [48] However, the Kalina cycle has not been commercially tested as much as the ORC.

The carbon dioxide transcritical power cycle uses $\mathrm{CO}_{2}$ as working medium. Some of the advantages of using $\mathrm{CO}_{2}$ are that it is non-toxic, relatively inert in the temperature range of interest, abundant in nature, and cheap [55-58].

\subsubsection{Thermoelectric generator}

In thermoelectric energy conversion, electricity is generated through the Seebeck effect, which occurs when a voltage difference is generated in a conductor or semiconductor because of a temperature gradient in the material $[59,60]$. The transfer of thermal energy through the material generates a movement of charge carriers, and when the circuit is closed the result is an electrical current. The thermoelectric voltage developed per unit temperature difference is called the Seebeck coefficient. [59]

A thermocouple consists of two semiconductors with different Seebeck coefficients. Several thermocouples can be connected electrically in series and thermally in parallel to form a module. The voltage output is directly proportional to the number of thermocouples. [61] A thermoelectric generator (TEG) is a system comprised of one or several thermo modules and a cooling system. A thermoelectric material has a specific temperature where the conversion efficiency is at its maximum. One way to increase the efficiency of a TEG is to establish a large temperature gradient across the TEG [60]. Commercially available thermoelectric materials can be divided into (1) low-temperature materials, up to about $250^{\circ} \mathrm{C}$ (e.g., materials based on bismuth telluride), (2) intermediate medium temperature materials, up to about $600^{\circ} \mathrm{C}$ (e.g., materials based on lead telluride), and (3) high-temperature materials, up to about $1000^{\circ} \mathrm{C}$ (e.g., materials based on silicon germanium alloys) [62]. To increase efficiency, research is conducted on new materials, e.g., nanomaterials. The TEG technology is a solidstate energy converter with no moving parts. [60]

\subsubsection{Thermophotovoltaic}

Thermophotovoltaic (TPV) is a process that produces electricity from infrared radiation (heat) from a high-temperature thermal source. The technology is principally the same as traditional photovoltaic (PV) technology in which solar radiation is absorbed by solar diode cells and converted into electricity. The PV cell is made of a semiconductor material in which the electrons in the valence band can be excited by photons and moved to the so-called conduction band whereby electricity is produced. The gap between the valence band and the conduction band is called the band gap. Photons must have higher energy than the band gap in order to excite electrons to the conduction band. In the TPV cell, the semiconductor material has a smaller band gap than in the traditional solar cell to match the infrared radiation, which has longer wavelength and less energy content. The shorter band gap results in increased efficiency in TPV compared to traditional PV. The efficiency of the system is increased if the spectrum of the heat radiation and the PV diode cell characteristics are matched. [63-66] The most common TPV cell materials are gallium antimonide, silicon, and indium gallium arsenide [67]. Construction and analysis of systems where TPV is combined with ORC [68] or TEG [69] have been conducted and reported. 


\subsubsection{Stirling engine}

The Stirling engine is a closed system in which the combustion of the fuel takes place externally; in other words, the combustion takes place outside the cylinder [70,71]. The hot gases from fuel combustion warm the working medium in the Stirling engine. At the same time, water or air cools the engine. The working medium, usually helium or hydrogen, is compressed and expanded due to the alternate heating and cooling, resulting in movement of the piston. When the engine is connected to a turbine and a generator, this results in generation of electricity and heat. [70,72] By transferring heat from the process to water, the engine can be used for combined heat and power (CHP) production; heat can be supplied, for example, to the DH network [70,71,73]. Today, the Stirling engines available for use in cogeneration plants are technically mature, but other Stirling engines are still under development. Exhaust gases and other excess heat sources could be used to drive CHP systems based on Stirling engines, and heat engines that can use these sources $\left(>500^{\circ} \mathrm{C}\right)$ are under development. [72,74] The temperature difference between the cold and hot sides determines the efficiency: a smaller temperature difference means lower efficiency [75].

\subsubsection{Phase Change Material engine}

The Phase Change Material (PCM) engine technology uses the volume expansion of a paraffin mixture when it changes from solid to liquid state to produce electricity from heat. A heat source heats the paraffin in the energy cell, and the paraffin melts and expands under high pressure. The paraffin is then cooled by water and changes back to a solid state. The work of expansion and contraction is captured in a hydraulic system, and the mechanical energy is converted into electricity in a generator. In one heat power cycle, the PCM changes from solid to liquid phase and then back to solid state. [76,77]

\subsubsection{Technology data}

Table presents data on the heat conversion technologies: electricity efficiency, temperature requirements, medium of the excess heat source, and stage of development.

Table 2. Technologies for conversion of heat into electricity.

\begin{tabular}{|c|c|c|c|c|}
\hline Technology & $\begin{array}{l}\text { Electricity } \\
\text { efficiency }(\eta)\end{array}$ & $\begin{array}{l}\text { Temperature } \\
\left({ }^{\circ} \mathrm{C}\right)\end{array}$ & $\begin{array}{l}\text { Medium of } \\
\text { the excess } \\
\text { heat } \\
\text { source }\end{array}$ & $\begin{array}{l}\text { Stage of } \\
\text { development }\end{array}$ \\
\hline $\begin{array}{l}\text { Rankine cycle } \\
\text { (traditional) }\end{array}$ & $\begin{array}{l}\text { Condensing } 0.47^{\mathrm{a}} \\
\text { CHP } 0.3^{\mathrm{c}}\end{array}$ & $>240^{b}$ & Gas, steam & Commercial \\
\hline $\begin{array}{l}\text { ORC } \\
\text { Kalina cvcle }\end{array}$ & $\begin{array}{l}0.05-0.2^{\mathrm{d}} \\
0.12-0.17^{\mathrm{e}}\end{array}$ & $\begin{array}{l}30-480^{d} \\
120-400^{f, g}\end{array}$ & $\begin{array}{l}\text { Gas, liquid } \\
\text { Gas, liquid }\end{array}$ & $\begin{array}{l}\text { Commercial } \\
\text { Commercial }\end{array}$ \\
\hline $\begin{array}{l}\mathrm{CO}_{2} \text { transcritical } \\
\text { power cycle }\end{array}$ & $0.025-0.08^{\mathrm{h}}$ & $60-150^{\mathrm{h}}$ & Gas, liquid & Development \\
\hline TEG & $0.01-0.05^{\mathrm{i}, \mathrm{j}}$ & $150-600^{\mathrm{j}, \mathrm{k}}$ & Gas, liquid & $\begin{array}{l}\text { Small-scale } \\
\text { commercial }\end{array}$ \\
\hline TPV & $0.1-0.2^{1, \mathrm{~m}}$ & $1000-1800^{1, \mathrm{~m}}$ & Radiation & Development \\
\hline Stirling engine & $0.13-0.36^{\mathrm{n}, \mathrm{o}, \mathrm{p}, \mathrm{q}}$ & $100-700^{\mathrm{o}, \mathrm{p}, \mathrm{q}, \mathrm{r}}$ & Gas, liquid & Development $^{\mathrm{s}}$ \\
\hline PCM engine & $0.025-0.09^{j}$ & $25-95^{t}$ & Water & Demonstration \\
\hline
\end{tabular}




\section{Calculation of heat recovery potentials}

In the calculation of heat recovery potentials in Gävleborg County and of the effects on global $\mathrm{CO}_{2}$ emissions, two different applications of external use of excess heat were considered: in Case (1), the industrial excess heat is recovered and used for DH; in Case (2), the industrial heat is used to generate electricity. These cases represent two extremes; in the first case, the heat is used as heat without any energy conversion; in the second case, the heat is converted to another energy form. It may have been an alternative to study heat cooperations other than $\mathrm{DH}$, but as excess heat delivery to DH systems commonly exists, DH was chosen to represent Case 1. Several possible combinations of electricity generating technologies could have been analyzed, but as the purpose of the study was to exemplify heat driven electricity generation, three technologies that complement each other with regard to temperature and medium of heat source were chosen.

Gaseous excess heat sources with temperatures below $80^{\circ} \mathrm{C}$ were not included in the calculations because no appropriate heat recovery technology was available. Excess heat sources with unknown temperature were also excluded from the calculations. The energy recovery potentials were calculated for each energy flow separately, but the results were then aggregated and presented (see Fig. 2) according to the recovery options described in Sections 8.1 and 8.2 .

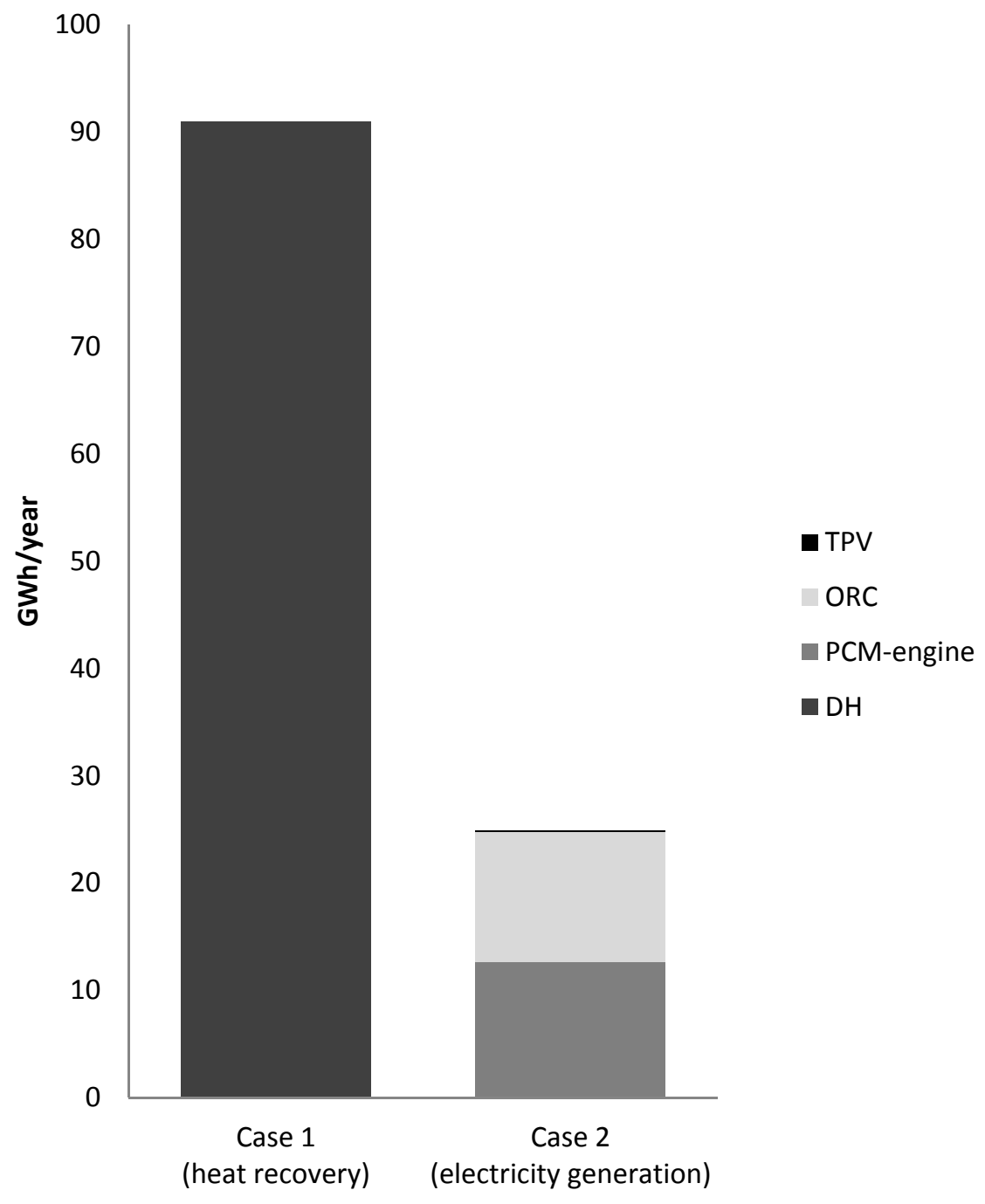

Fig. 2. Heat recovery (Case 1) and electricity generation (Case 2) using industrial excess heat. 


\subsection{Heat delivery to a district heating network}

The $\mathrm{DH}$ system was assumed to have a supply temperature, $\mathrm{T}_{\mathrm{S}}$, of $90^{\circ} \mathrm{C}$ and a return temperature, $\mathrm{T}_{\mathrm{R}}$, of $50^{\circ} \mathrm{C}$. $^{5}$ Heat sources with temperatures below $95^{\circ} \mathrm{C}$ were considered not to be feasible for DH production. Values of temperature and mass flow rate of the excess heat flows were provided by the companies answering the questionnaire, while specific heat capacity and density of the heat carrier are tabulated values. ${ }^{6}$ If the excess heat source is water, Eq. (1) (derived from [30]) is used to calculate the heat, $\mathrm{Q}_{\text {tr }}(\mathrm{Wh})$, which could be transferred from industry to the DH system.

$\mathrm{Q}_{\mathrm{tr}}=\mathrm{c}_{\mathrm{p}} \cdot \mathrm{m} \cdot\left(\mathrm{T}_{\mathrm{ex}, \mathrm{in}}-\mathrm{T}_{\mathrm{R}}-\theta\right)$

where $c_{p}$ is the specific heat capacity $(\mathrm{kJ} / \mathrm{kg} \mathrm{K})$ of the excess heat source, $\mathrm{m}$ is the mass $(\mathrm{kg})$ of the excess heat source and $\mathrm{T}_{\mathrm{ex}, \mathrm{in}}\left({ }^{\circ} \mathrm{C}\right)$ is the temperature of the industrial excess heat before the heat exchanger. The temperature difference $\theta=\left(T_{e x, i n}-T_{S}\right)$ is a measure of the performance of the heat exchanger and in this study $\theta$ was set at $5^{\circ} \mathrm{C}$ (as recommended by [30]).

For gaseous heat sources, Eq. (2) (derived from [30]) was used to calculate heat recovery potentials.

$\mathrm{Q}_{\mathrm{tr}}=\mathrm{c}_{\mathrm{p}} \cdot \mathrm{m} \cdot\left(\mathrm{T}_{\mathrm{ex}, \mathrm{in}}-\mathrm{T}_{\mathrm{min}}\right)$

where $\mathrm{T}_{\min }\left({ }^{\circ} \mathrm{C}\right)$ is the minimum temperature that the excess heat source can be cooled to without causing corrosions. In this study $\mathrm{T}_{\min }$ was set at $100^{\circ} \mathrm{C}[30]$.

Recovery of heat from hot material was calculated based on Nilsson [22], and it was assumed that $25 \%$ of the heat in hot material could be transferred to water and used as $\mathrm{DH}$.

\subsection{Heat recovery for electricity generation}

Three technologies were chosen for the calculations of electricity generation:

- TPV for heat from hot material with a temperature above $1000^{\circ} \mathrm{C}$

- ORC for excess heat sources (liquid and gaseous) with temperatures above $80^{\circ} \mathrm{C}$.

- PCM engine for liquid excess heat sources with temperatures below $80^{\circ} \mathrm{C}$.

These technologies have different preferred temperature ranges for the heat source and complement each other. Johansson and Söderström [6] showed that ORC is the better choice for liquid heat sources with temperatures above $80^{\circ} \mathrm{C}$ and that $\mathrm{PCM}$ engine technology is the better choice for liquid heat sources below $80^{\circ} \mathrm{C}$. ORC, rather than a $\mathrm{CO}_{2}$ transcritical power cycle, was studied because ORC is a mature technology, and more information about its conversion efficiencies could be found. Electricity could be generated from hot material by first transferring the heat to water and then producing electricity from hot water, but this means unnecessary losses. TPV can produce electricity directly from heat radiation and does not require harvesting technologies. In the calculation of electricity generation with TPV, a conversion efficiency of 0.2 was used [67].

\footnotetext{
${ }^{5} \mathrm{In}$ Sweden, supply temperature in a typical $\mathrm{DH}$ system varies between $80^{\circ} \mathrm{C}$ and $110^{\circ} \mathrm{C}$; return temperature varies between $45^{\circ} \mathrm{C}$ and $55^{\circ} \mathrm{C}$, depending on season [30].

${ }^{6}$ Values for $\mathrm{c}_{\mathrm{p}}$ and density of water were taken from The Engineering Toolbox [89]. Values for $\mathrm{c}_{\mathrm{p}}$ and density of flue gases were taken from "Pipe flow calculations" [90]. The chemical composition of the flue gases was assumed to be $13 \% \mathrm{CO}_{2}, 11 \% \mathrm{H}_{2} \mathrm{O}$, and $76 \% \mathrm{~N}_{2}$.
} 
For the calculation of electricity generation, $\mathrm{Q}_{\mathrm{el}}(\mathrm{Wh})$, with $\mathrm{ORC}$, Eq. (3) was used [91].

$Q_{\mathrm{el}}=Q_{\mathrm{th}} \cdot \eta \cdot\left(\frac{\mathrm{T}-\left(30+\mathrm{T}_{\mathrm{diff}}\right)}{\mathrm{T}-30}\right)$

where $\mathrm{Q}_{\text {th }}(\mathrm{Wh})$ is the energy content of the excess heat source, $\mathrm{\eta}$ is the electricity efficiency of the ORC, T $\left({ }^{\circ} \mathrm{C}\right)$ is the temperature of the excess heat source, and $\mathrm{T}_{\text {diff }}\left({ }^{\circ} \mathrm{C}\right)$ is the temperature difference between outgoing excess heat flow from the boiler in the ORC and incoming flow of working medium in the ORC. $\mathrm{T}_{\text {diff }}$ was set at $20^{\circ} \mathrm{C}$ for liquid excess heat flows [91] and $70^{\circ} \mathrm{C}^{7}$ for gaseous excess heat flows. Evaporation temperature was set at $30^{\circ} \mathrm{C}$ for the working medium in the ORC [92], and electricity efficiency was set at 0.084 [6].

Electricity generation, $\mathrm{Q}_{\mathrm{el}}(\mathrm{Wh})$, in a PCM engine was calculated using Eq. (4) [6].

$\mathrm{Q}_{\mathrm{el}}=\mathrm{Q}_{\mathrm{th}} \cdot 0.024 \cdot \frac{\mathrm{T}_{\mathrm{diff}}}{25} \cdot \frac{1}{\mathrm{k}^{2}} \cdot \sum_{\mathrm{i}=0}^{\mathrm{k}-1}(\mathrm{k}-\mathrm{i})$

where $\mathrm{Q}_{\text {th }}(\mathrm{Wh})$ is the energy content of the excess heat source that is used by the PCM engine, $\mathrm{T}_{\text {diff }}\left({ }^{\circ} \mathrm{C}\right)$ is the temperature difference between ingoing excess heat flow and incoming cooling water. The number of cascades, $\mathrm{k}$, depends on minimum available temperature difference between heat source and heat sink, $\mathrm{T}_{\text {diffmin }}\left({ }^{\circ} \mathrm{C}\right)$, during operation time with respect to seasonal variations:

$\mathrm{k}=1$, if $20^{\circ} \mathrm{C} \leq \mathrm{T}_{\text {diffmin }}<40^{\circ} \mathrm{C}$

$\mathrm{k}=2$, if $40^{\circ} \mathrm{C} \leq \mathrm{T}_{\text {diffmin }}<60^{\circ} \mathrm{C}$

$\mathrm{k}=3$, if $60^{\circ} \mathrm{C} \leq \mathrm{T}_{\text {diffmin }}<80^{\circ} \mathrm{C}$

and $\mathrm{Q}_{\text {th }}$ depends on the number of cascades, as the temperature difference between ingoing and outgoing excess heat flow is $(\mathrm{k} \cdot 10)^{\circ} \mathrm{C}$.

\section{Utilizing the industrial excess heat in Gävleborg County}

Based on the data and assumptions presented in Section 8, the energy recovery potential from using the available industrial excess heat was calculated. Fig. 2 presents the two cases studied, i.e., heat recovery in the DH network (Case 1) and for electricity generation (Case 2).

In the case of heat recovery for heating purposes, only heat flows with temperatures $\geq 95^{\circ} \mathrm{C}$ were assumed to be recovered for deliveries to the DH network. Excess heat flows with temperatures lower than the supply temperature are too low to be heat-exchanged to the supply system, so they were not considered for heat supply. These low-temperature heat flows (as in Case 2) could be used for electricity generation using the PCM engine. The PCM engine could be used in combination with heat deliveries to the $\mathrm{DH}$ system; the potential presented in the bar representing electricity generation from PCM engine in Case 2 (approximately $13 \mathrm{GWh} /$ year) could be added to the output of heat recovery in Case 1, increasing the recovery potential. Calculations were made for the following electricity generating technologies: PCM engine, ORC, and TPV, depending on the heat source temperature and heat source medium. The amount of electricity generated by using these technologies is illustrated in Case 2 of Fig. 2, which shows that the amount of recovered

\footnotetext{
${ }^{7}$ This temperature was chosen because, in this study, the minimum temperature that the flue gases would be cooled to was set at $100^{\circ} \mathrm{C}$ to avoid problems with corrosion.
} 
energy output would be greater when the excess heat is used for heat recovery in the DH system, compared to electricity generation.

\section{0. $\mathrm{CO}_{2}$ emissions evaluation}

The use of industrial excess heat for deliveries to the $\mathrm{DH}$ network reduces global $\mathrm{CO}_{2}$ emissions in four scenarios (EMS-1, EMS-2, EMS-3, and EMS-6), while the use of excess heat for electricity generation reduces $\mathrm{CO}_{2}$ emissions in all the scenarios (see Fig. 3)

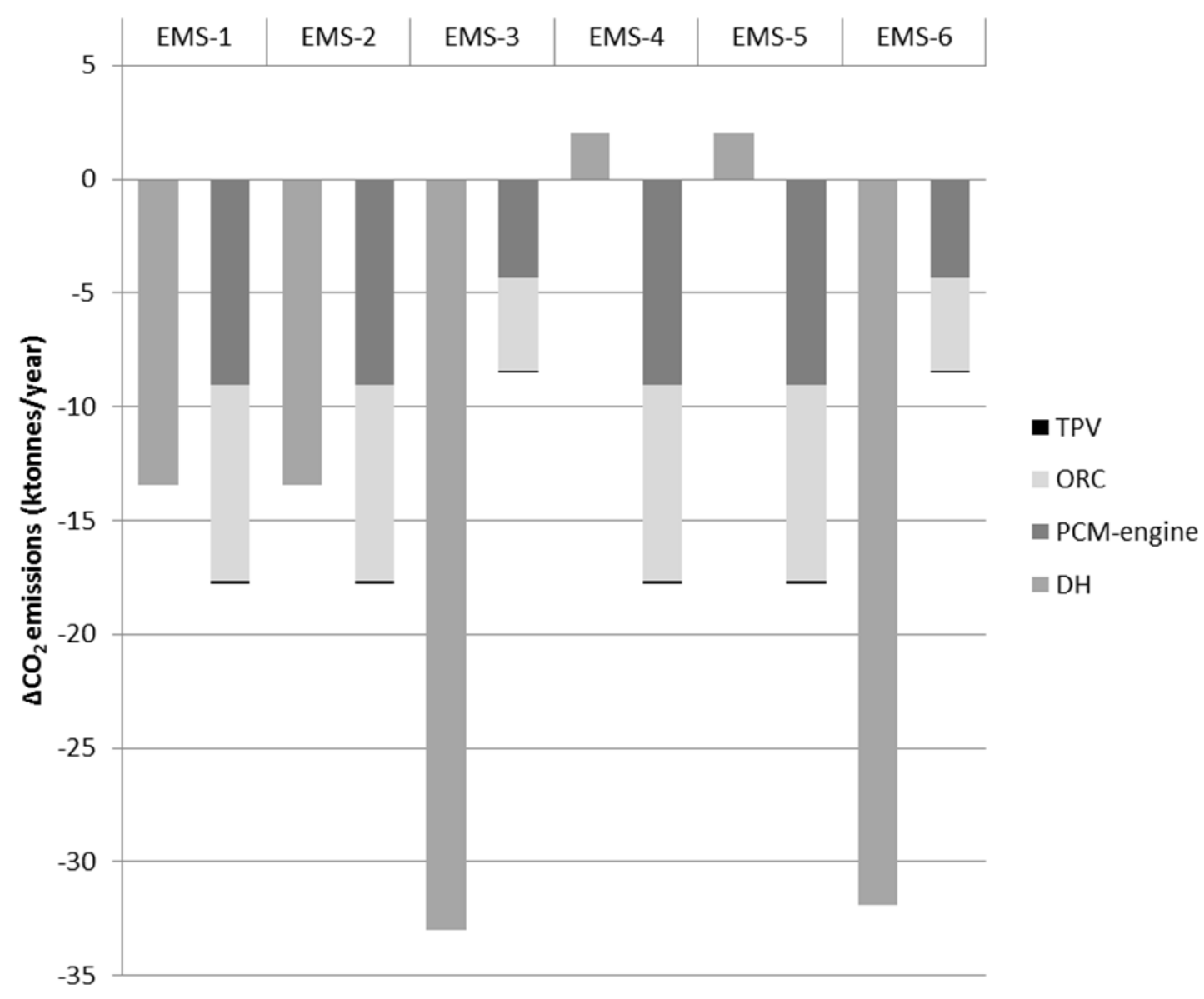

Fig. 3. Global $\mathrm{CO}_{2}$ emissions change from heat utilization (Case 1: DH) and electricity production (Case 2: TPV, ORC, and PCM engine) using industrial excess heat. Negative values indicate reduced emissions.

Since electricity generation from industrial excess heat is assumed to replace marginal electricity production in a coal power plant or a natural gas combined cycle (NGCC), such electricity generation would reduce global $\mathrm{CO}_{2}$ emissions. The size of reduction depends on the marginal technology for electricity production. The $\mathrm{CO}_{2}$ mitigation is greater when the marginal electricity producer is a coal power plant rather than an NGCC.

When heat is exported to a $\mathrm{DH}$ network, the impact on global $\mathrm{CO}_{2}$ emissions depends on the type of heating system it replaces. When the DH system is based on bio-HOB (EMS-1 to EMS-3), excess heat deliveries would result in reduced global $\mathrm{CO}_{2}$ emissions, independent of 
the marginal user of biofuels and build margin technology for electricity. When the DH system is based on bio-CHP (EMS-4 to EMS-6), global $\mathrm{CO}_{2}$ emissions would increase if the marginal user of biofuels is a producer of FT diesel and the build margin technology for electricity is a coal power plant (EMS-4 to EMS-5). This is due to large $\mathrm{CO}_{2}$ emissions that are derived from marginal electricity production in the coal-fired power plant to compensate for the reduced production in the CHP plant. In EMS-6, the build margin technology for electricity production is an NGCC and, in addition, the marginal user of biofuels is a coal power plant. In this case, industrial excess heat delivery would result in reduced global $\mathrm{CO}_{2}$ emissions. Heat delivery to a bio-CHP system would result in reduced heat production and, hence, reduced electricity production in the CHP plant. Consequently, more electricity has to be produced by the marginal electricity producer. This explains why industrial excess heat delivery to a bio-HOB system would be more advantageous in terms of global $\mathrm{CO}_{2}$ emissions than heat delivery to a bio-CHP system.

In EMS-3 and EMS-6, where the marginal user of biofuels is a coal power plant and the build margin technology for electricity production is NGCC, excess heat delivery to a $\mathrm{DH}$ system would be more advantageous, in terms of $\mathrm{CO}_{2}$ emissions mitigation, than using the heat to produce electricity. However, in all other scenarios, the better option would be to produce electricity. This is partly due to the electricity production from excess heat replacing electricity production in coal power plants. When the DH system is based on bio-CHP, the change in emissions related to the recovery technologies depends not only on the marginal user of biofuels, but also on the build margin technology for electricity. Using biomass in a coal power plant reduces global $\mathrm{CO}_{2}$ emissions more than using it to produce transportation fuel.

It is noteworthy that in Case 1, with heat recovery to a DH system, excess heat sources with temperatures below $95^{\circ} \mathrm{C}$ are not utilized, but in Case 2 these excess heat streams are used. If these heat streams were used to produce electricity and added to the heat deliveries presented in Case 1, this would result in additional reductions in global $\mathrm{CO}_{2}$ emissions. Nevertheless, the reductions would remain greater for Case 2, compared to Case 1 in EMS-1, EMS-2, EMS4, and EMS-5. When DH delivery and electricity production is combined, it would result in global $\mathrm{CO}_{2}$ mitigations in all scenarios.

\section{Discussion}

The study reveals the existence of large untapped excess heat potentials that when recovered may reduce the global $\mathrm{CO}_{2}$ emissions (i.e., the climate impact). The study focused on the utilization of the excess heat in $\mathrm{DH}$ systems or heat-based electricity production for internal and/or external use. The recovery measures presented, which are in different stages of progress; from development to large-scale commercial use, all offer interesting options to recover and use industrial excess heat today or in the future.

While this study considered three different technologies in calculating potential electricity generation from industrial excess heat, a single industry may find it too expensive to invest in three technologies. The quality and quantity of the heat sources could guide the industry in choosing the electricity generation technology with the greatest potential. This might lead to a lower electricity output because of unused excess heat flows, but the economic gains may be higher. In the study, excess heat sources with temperatures less than $95^{\circ} \mathrm{C}$ were excluded for export to DH systems. It may be possible to elevate the temperatures by using a heat pump and thus increase the recovery potential. However, the increased energy recovery potential has to be larger than the energy used by the heat pump. 
The DH systems in Gävleborg County differ from each other in terms of heat generation systems. However, in the calculations of effects on global $\mathrm{CO}_{2}$ emissions, two average Swedish DH systems were used: one CHP-based and one HOB-based DH system. The heat demand in the local DH systems and seasonal variations may affect the possibilities for heat recovery in the DH system. Combining different excess heat recovery technologies may increase the use of excess heat. For example, heat-driven cooling processes may be combined with DH systems to increase the heat demand during summer time and prolong the period of utilization of excess heat. Currently, 11\% of the heat supply in the DH system in Gävleborg County originates from industrial excess heat. This study shows that the approximate energy recovery output that could be used for DH deliveries would be $91 \mathrm{GWh}$ per year. Therefore, there are potentials for additional supply of industrial excess heat to the system in Gävleborg County. However, it is hard to predict future heat potentials because the available excess heat depends on future energy efficiency measures and production levels in industry. Although there is a potential for export of industrial excess heat to the DH network, several factors affect the probability of an actual implementation. For example, there are economic barriers such as a long payback period, the distance between industry and the DH network [93], and the risk of an unsecure heat supply from industry.

The results showed that the energy recovery output would be less than half the amount if the excess heat were used to produce electricity than if the heat was recovered for use in a DH system. The effects on global $\mathrm{CO}_{2}$ emissions depend on the future energy system, which is here represented with different EMS. In all the scenarios used, except for EMS-3 and EMS-6, the better option would be to produce electricity than to deliver heat to a DH system. EMS-3 and EMS-6 are the scenarios in which the marginal biomass user is a coal power plant and the build margin technology for electricity is an NGCC plant. Excess heat recovery to the DH network in EMS-3 and EMS-6 releases biomass that can replace electricity production in a coal power plant. This shows the great impact that reducing electricity production in coal power plants has on global $\mathrm{CO}_{2}$ emissions. Excess heat sources with temperatures lower than $95^{\circ} \mathrm{C}$ were assumed to be unfeasible for $\mathrm{DH}$ production, but these heat sources could be used for electricity production, changing the outcome of Case 1. Combined heat export to a DH system and electricity generation would further reduce the $\mathrm{CO}_{2}$ emissions in the heat recovery case (see Fig. 3).

While it is difficult to predict the development of the energy market, the scenario methodology provided a sensitivity analysis of possible future energy markets; those used in this study are consistent in terms of the correlation between different energy prices. Moreover, the input to the scenarios consisted of predictions of fossil fuel prices from World Energy Outlook 2011 [18]. As shown in the results of global $\mathrm{CO}_{2}$ emissions, the choice of scenario is crucial for the outcome of the scenario analysis. Results from the analysis of excess heat recovery options, using different energy markets scenarios, show the importance of a holistic view when investing in new technologies and planning changes in energy systems in order to avoid sub-optimizations.

In this study, the internal use of excess heat was not analyzed. However, Jönsson et al. [8], who studied trade-offs between internal and external use of excess heat from a kraft pulp mill, concluded that external use of excess heat would result in larger reductions of global $\mathrm{CO}_{2}$ emissions than would internal use.

Because the questionnaire response rate was only 33\%, the excess heat potential may be underestimated. Moreover, some of the respondents did not specify the quantity and/or quality of the reported heat sources; hence, these excess heat sources were not included in the 
analysis. The study does not claim to review the whole market of heat recovery options; nonetheless, it reveals several possibilities for heat recovery.

\section{Conclusions}

The study revealed large untapped excess heat potentials. The reported excess heat flows represented approximately $8.4 \%$ of the energy used by the companies studied in Gävleborg County. The energy recovery output is greater when excess heat is used for heating purposes in a DH system than being used for heat-driven electricity generation. Utilization of available industrial excess heat can lead to reductions in global $\mathrm{CO}_{2}$ emissions, but the effects on the emissions depend on the energy market. From a climate change perspective, the results show that if the marginal user of biofuels is a coal power plant and the build margin technology for electricity is an NGCC, it would be better to use industrial excess heat from Gävleborg County in a DH system based on biofuel combustion than to produce electricity from the heat. However, if the marginal user of biofuels is a producer of FT diesel and the build margin technology for electricity is a coal power plant, the better option would be to produce electricity from the excess heat. The results show the importance of analyzing different cornerstones of the future energy market development, and to have a holistic view and broaden the system perspective when planning new investments and policy instruments.

\section{Acknowledgements}

This work was carried out under the auspices of the Energy Systems Programme, which is funded primarily by the Swedish Energy Agency. The work was co-financed by Göranssonska fonden, which is a trust fund. The authors would like to thank the respondents for giving their time to answer the questionnaire. We would also like to thank our colleagues at the Division of Energy Systems at Linköping University, especially Magnus Karlsson and Mats Söderström, for valuable comments and input.

\section{References}

[1] EC (European Commission). Communication from the Commission, Europe 2020 A strategy for smart, sustainable and inclusive growth. Brussels, Belgium; 2010.

[2] EC (European Commission). Directive of the European Parliament and of the Council on energy efficiency 2011/1072 (COD). Brussels, Belgium; 2011.

[3] SEA (Swedish Energy Agency). Policy instruments for industrial excess heat. (Styrmedel för industriell spillvärme) Report no. ER 2008:15. Eskilstuna, Sweden: Swedish Energy Agency; 2008 [in Swedish].

[4] Thekdi A., Belt C. Waste heat reduction and recovery options for metal industry in The Minerals, Metals \& Materials Society (TMS). Energy Technology 2011: Carbon Dioxide and Other Greenhouse Gas Reduction Metallurgy and Waste Heat Recovery. John Wiley \& Sons Inc; 2011:17-24.

[5] DOE (U.S. Department of Energy). Waste Heat Recovery: technology and Opportunities in U.S. Industry. U.S. Department of Energy, BCS Incorporated; 2008.

[6] Johansson MT., Söderström M. Electricity generation from low temperature industrial excess heat - an opportunity for the steel industry. Energy Efficiency 2013, DOI:10.1007/s12053-013-9218-6. 
[7] Jönsson J., Pettersson K., Berntsson T., Harvey S. Comparison of options for utilization of a potential steam surplus at kraft pulp mills - Economic performance and $\mathrm{CO}_{2}$ emissions. International Journal of Energy Research 2012, DOI:10.1002/er.2905.

[8] Jönsson J., Svensson I-L., Berntsson T., Moshfegh, B. Excess heat from Kraft pulp mills: Trade-offs between internal and external use in the case of Sweden - Part 2: Results for future energy market scenarios. Energy Policy 2008;36(11):4186-4197.

[9] Wolf A., Eklund M., Söderström M. Developing integration in a local industrial ecosystem - an explorative approach. Business Strategy and the Environment 2007;16:442445.

[10] Cronholm L.Å., Grönkvist S., Saxe M. Excess heat from industries and heat recovery from premises. (Spillvärme från industrier och lokaler) Report no. 2009:12. Swedish District Heating Association; 2009 [in Swedish].

[11] Broberg S., Backlund S., Karlsson M., Thollander P. Industrial excess heat deliveries to Swedish district heating networks: Drop it like it's hot. Energy Policy 2012;51:332-339.

[12] Statistics Sweden. Demographic. Avaliable at: www.scb.se [in Swedish].

[13] Statistics Sweden. Energy. Avaliable at: www.scb.se [in Swedish].

[14] Swedish District Heating Association, 2010. Excess heat 2010 (Överskottsvärme 2010) Excel sheet accessed through personal communication [in Swedish].

[15] Ministry of the Environment. Constitution on environmental hazardous activities and health, 1998:899, 1998.

[16] Axelsson E., Harvey S. Scenarios for assessing profitability and carbon balances of energy investments in industry - Pathways to sustainable European energy systems. AGS Pathways report: 2010:EU1. Gothenburg, Sweden: AGS, The alliance for global sustainability; 2010.

[17] Axelsson E., Harvey S., Berntsson T. A tool for creating energy market scenarios for evaluation of investments in energy intensive industry. Energy 2009;34(12):2069-2074.

[18] IEA (International Energy Agency). World Energy Outlook 2011. 2011.

[19] Çengel YA, Turner RH, Cimbala JM. Fundamentals of Thermal-Fluid Sciences. Third edition. Mc Graw-Hill Companies, Inc. New York; 2008.

[20] Tian Y, Zhao CY. A review of solar collectors and thermal energy storage in solar thermal applications. Applied Energy 2013;104:538-553.

[21] Johansson MT., Wren J., Söderström M. Quantification and recovery of excess heat from cooling beds - a case study at a steel plant. Submitted to Applied Energy 2013.

[22] Nilsson J. Heat recovery from cooling beds in the iron and steel industry: heat from the cooling beds - 100 times better than solar! (Värmeåtervinning från svalbäddar inom järn- och stålindustrin - Värme från svalbäddar - 100 gånger bättre än solvärme!) Report no. D809. Jernkontoret; 2003 [in Swedish].

[23] Chua K.J., Chou S.K., Yang W.M. Advances in heat pump systems: A review. Applied Energy 2010;87:3611 - 3624.

[24] Farid M. M., Khudhair A. M., Razack S. A. K., Al-Hallaj S. A review on phase change energy storage: Materials and applications. Energy Conversion and Management 2004;45:1597 - 1615 .

[25] Farid MM., Khudhair AM., Razack SAK., Al-Hallaj S. A review on phase change energy storage: materials and applications. Energy Conversion and Management 2004;45:15971615 .

[26] Hasnain SM. Review on sustainable thermal energy storage technologies, Part I: Heat storage materials and techniques. Energy Conversion and Management 1998;39(11):11271138 . 
[27] Zalba B., Marín JM., Cabeza LF., Mehling H. Review on thermal energy storage with phase change: materials, heat transfer analysis and applications. Applied Thermal Engineering 2003;23:251-283.

[28] Ericsson K. Introduction and development of the Swedish district heating system Critical factors and lessons learned. Report as a part of the IEE project "Policy development for improving RES-H/C penetration in European Member States". Lund University, Lund, Sweden, 2009.

[29] Rezaie B. and Rosen M.A. District heating and cooling: Review of technology and potential enhancements. Applied Energy 2011;93: 2-10.

[30] Optensys Energianalys AB. Proposal for accounting of excess heat when designing new district heating systems. (Förslag till princip för redovisning av restvärmepotential vid projektering av ny fjärrvärmeproduktion) Linköping, Sweden: Optensys; 2012 [in Swedish].

[31] Frederiksen S., Werner S. District heating, theory, technology and function. (Fjärrvärme : teori, teknik och funktion) Studentlitteratur, Lund, Sweden; 1993 [In Swedish].

[32] Wiltshire R. Low temperature district energy systems. Proceedings of 16th Building Services, Mechanical and Building Industry Days International Conference, Debrecen, Hungary, 14-15 October 2011.

[33] Ajah A.N., Patil A.C., Herder P.M., Grievink J. Integrated conceptual design of a robust and reliable waste-heat district heating system. Applied Thermal Engineering 2007;27:11581164.

[34] Rydstrand M., Martin V., Westermark M. Heat driven cooling. (Värmedriven kyla) Report no. FOU 2004:112. Stockholm, Sweden: Swedish District Heating Association; 2004 [in Swedish].

[35] Trygg L., Amiri S. European perspective on absorption cooling in combined heat and power system - A case study on energy utility and industries in Sweden. Applied Energy 2007;88(12):1319-1337.

[36] Lindmark S. The Role of Absorption Cooling for Reachin Sustaniable Energy Systems. Licentiate Thesis, Royal Institute of Technology, Stockholm, Sweden, 2005.

[37] Srikhirin P., Aphornratana S., Chungpaibulpatana S. A review of absorption refrigeration technologies. Renewable and Sustainable Energy reviews 2001; 5:343-372.

[38] Svensson I.L. Evaluating system concequences of energy-co-operation between industries and utilities. Linköping Studies in Science and Technology, Dissertation nr. 1407, Linköping University, Linköping, Sweden, 2011.

[39] Martin M., Eklund, M. Improving the environmental performance of biofuels with industrial symbiosis. Biomass and Bioenergy 2011;35:1747-1755.

[40] Jacobsen N.B. Industrial Symbiosis in Kalundborg, Denmark: A Quantitative Assessment of Economic and Environmental Aspects. Journal of Industrial Ecology 2006;10(1-2):239-255.

[41] Wolf A. Energy-efficient pellet production in the forest industry - a study of obstacles and success factors. Biomass and Bioenergy 2006;30:38-45.

[42] Ellersdorfer M., Weiss C. Integration of biogas plants in the building materials industry. Proceedings of WREC, Linköping, Sweden, 8-13 May, 2011.

[43] Li H., Chen Q., Zhang X., Finney K.N., Sharifi V.N., Swithenbank J. Evaluation of a biomass drying process using waste heat from process industries: A case study. Applied Thermal Engineering 2012;35:71-80.

[44] Chinese D., Meneghetti A., Nardin G. Waste-to-energy based greenhouse heating: exploring viability conditions through optimization models. Renewable Energy 2005;30:1573-1586.

[45] Andrews R., Pearce J.M. Environmental and economic assessment of greenhouse waste heat exchange. Journal of Cleaner Production 2011;19:1446-1454. 
[46] Andersson V., Broberg S., Hackl R. 2012. Integrated algae cultivation for municipal wastewater treatment and biofuels production in industrial clusters. Proceedings of WREF, Denver, USA, 13-17 May, 2012.

[47] Fahlén E., Trygg L., Ahlgren E. O. Assessment of absorption cooling as a district heating system strategy - A case study. Energy Conversion and Management 2012;60:115 - 124.

[48] Law R., Harvey A., Reay D. Opportunities for low-grade heat recovery in the UK food processing industry. Applied Thermal Engineering 2012, DOI:10.1016/j.applthermaleng.2012.03.024.

[49] US department of Energy. Waste heat recovery: Technology and opportunities in U.S. industry. $2008 . \quad$ Available at: www1.eere.energy.gov/manufacturing/intensiveprocesses/pdfs/waste_heat_recovery.pdf [50] Nguyen T.Q., Slawnwhite J.D., Boulama K.G. Power generation from residual industrial heat. Energy Conversion and Management 2010;51:2220 - 2229.

[51] Stijepovic M.Z., Linke P., Papadopoulos A.I., Grujic A.S. On the role of working fluid properties in Organic Rankine Cycle performance. Applied Thermal Engineering 2012;36:406-413.

[52] Quoilin S., Declaye S., Tchanche B.F., Lemort V. Thermo-economic optimization of waste heat recovery Organic Rankine Cycles. Applied Thermal Engineering 2011;31:28852893.

[53] Liu B-T., Chien K-H., Wang C-C. Effect of working fluids on organic Rankine cycle for waste heat recovery. Energy 2004;29:1207-1217.

[54] Dai Y., Wang J., Gao L. Parametric optimization and comparative study of organic Rankine cycle (ORC) for low grade waste heat. Energy Conversion and Management 2009;50:576-582.

[55] Vélez F., Chejne F., Antolin G., Quijano A. Theoretical analysis of a transcritical power cycle for power generation from waste energy at low temperature heat source. Energy Conversion and Management 2012;60:188-195.

[56] Guo, T., Wang, H., Zhang, S. Comparative analysis of natural and conventional working fluids for use in transcritical Rankine cycle using low-temperature geothermal source. International Journal of Energy Research 2011;35(6):530-544.

[57] Ayachi, F., Ksayer, E.B., Neveu, P. Exergy assessment of recovery solutions from dry and moist gas available at medium temperature. Energies 2012; 5(3):718-730.

[58] Marchioro Ystad PA., Lakew AA., Bolland O. Integration of low-temperature transcritical $\mathrm{CO}_{2}$ Rankine cycle in natural gas-fired combined cycle (NGCC) with postcombustion $\mathrm{CO}_{2}$ capture. International Journal of Greenhouse Gas Control 2013;12:213-219

[59] Kasap S. Thermoelectric effects in metals: Thermocouples. 2001. Avaliable at: http://kasap3.usask.ca/samples/Thermoelectric-Seebeck.pdf

[60] Hadjustassou C., Kyriakides E., Georgiou J. Designing high efficiency segmented thermoelectric generators. Energy Conversion and Management 2013;66:165 - 172.

[61] Rowe D.M. General Principles and Basic Considerations in Thermoelectric handbook from macro to nano. CRC Press: e-book; 2005:1.4-1.14.

[62] Qiu K, Hayden A.C.S. Integrated Thermoelectric and Organic Rankine Cycles for MicroCHP Systems. Applied Energy 2012, DOI:10.1016/j.apenergy.2011.12.072.

[63] Chubb DL. Fundamentals of thermophotovoltaic energy conversion. Amsterdam, Elsevier; 2007.

[64] Luque A, Hegedus S. Handbook of Photovoltaic Science and Engineering. Second Edition. John Wiley \& Sons; 2011. 
[65] Ramakumar R., Barnett AM., Kazmerski LL., Benner JP., Coutts TJ. Power Systems and Generation. In Dorf, RC. (Ed). The Electrical Engineering Handbook. Boca Raton: CRC Press LLC; 2000. Available electronic at: ENGnetBASE.

[66] Utlu Z., Parali U. Investigation of the potential of thermophotovoltaic heat recovery for the Turkish industrial sector. Energy Conversion and Managemnet 2013;74:308 - 322.

[67] Bauer T., Forbes I., Pearsall N. The potential of thermophotovoltaic heat recovery for the UK industry. International Journal of Ambient Energy 2004;25:19-25.

[68] De Pascale A., Ferrari C., Melino F., Morini M., Pinelli M. Integration between a thermophotovoltaic generator and an Organic Rankine Cycle Applied Energy 2012;97:695-703.

[69] Qiu K., Hayden A.C.S. Development of a novel cascading TPV and TE power generation system. Applied Energy 2012;91(1):304-308.

[70] Persson C., Olsson J. Comparison of various co-generation technologies. (Jämförelse mellan olika kraftvärmeteknologier) Report no. SGC 128. Malmö, Sweden: Swedish Gas Technology Centre; 2002 [in Swedish].

[71] Kong X.Q., Wang R.Z., Huang X.H . Energy efficiency and economic feasibility of CCHP driven by stirling engine. Energy Conversion and Management 2004; 45 (9-10) :14331442.

[72] SLU (Swedish University of Agricultural Science). Profitability of Small-Scale Combined Heat and Power Production Using Biofuels - Conditions and Future Prospects. (Lönsamhet för småskalig biobränslebaserad kraftvärme - förutsättningar och framtidsutsikter) Report no. 033. Uppsala, Sweden: Swedish University of Agricultural Science; 2011 [in Swedish].

[73] Moghadam R.S., Sayyaadi H., Hosseinzade H. Sizing a solar dish Stirling micro-CHP system for residential application in diverse climatic conditions based on $3 \mathrm{E}$ analysis. Energy Conversion and Management 2013;75:348-365.

[74] Li T., Tang DW., Li Z., Du J., Zhou T., Jia Y. Development and test of a Stirling engine driven by waste gases for micro-CHP system. Applied Thermal Engineering 2012;3334:119-123.

[75] Hsu ST., Lin FY., Chiou JS. Heat-transfer aspects of Stirling power generation using incinerator waste energy. Renewable Energy 2003;28:59-69.

[76] Exencotech. Avaliable at: www.exencotech.se. Accessed 2013-03-01

[77] Östlund B. CEO of Exencotech AB. Personal communication 2011-11-30.

[78] Hansson H., Larsson S-E., Nyström O., Olsson F., Ridell B. Electricity from new facilities 2007 - a comparison between different technologies for electricity generation with regard to costs and development prospects (El från nya anläggningar 2007 - Jämförelse mellan olika tekniker för elgenerering med avseende på kostnader och utvecklingstendenser). Report no. 07:50. Stockholm, Sweden: Elforsk; 2007 [In Swedish].

[79] Brodén H, Nyström O, Jönsson M. Optimum power yield for bio fuel fired combined heat and power plants (Optimal elverkningsgrad för biobränsleeldade kraftvärmeverk). Anläggnings- och förbränningsteknik 1236. Stockholm, Sweden: Värmeforsk; 2012. (in Swedish)

[80] Vélez F., Segovia J.J., Martín M.C., Antolín G., Chejne F., Quijano A. A technical, economical and market review of organic Rankine cycles for the conversion of low-grade heat for power generation. Renewable and Sustainable Energy Reviews 2012;16(6):4175-4189.

[81] Ogriseck, S. Integration of Kalina cycle in a combined heat and power plant, a case study. Applied Thermal Engineering 2009;29:2843-2848

[82] Zhang X., He M., Zhang Y. A review of research on the Kalina cycle. Renewable and Sustainable Energy Reviews 2012;16(7):5309-5318. 
[83] Bombarda P., Invernizzi CM., Pietra C. Heat recovery from Diesel engine: A thermodynamic comparison between Kalina and ORC cycles. Applied Thermal Engineering 2010;30:212-219.

[84] Ventosa i Capell V., Tarragó S., Maria J. Analysis of possibilities for 1MW electricity generation from waste heat in the port of Rotterdam. Master thesis, Universitat Politécnica de Catalunya, Barcelona, Spain, 2011.

[85] Dughaish Z.H. Lead telluride as a thermoelectric material for thermoelectric power generation. Physica B: Condensed Matter 2002;322(1-2):205-223.

[86] Rogdakis ED, Antonakos GD, Koronaki IP. Thermodynamic analysis and experimental investigation of a Solo V161 Stirling cogeneration unit. Energy 2012;45(1): 503-511.

[87] Chen C-L, Ho C-E, Yau H-T. Performance Analysis and Optimization of a Solar Powered Stirling Engine with Heat Transfer Considerations. Energies 2012;5(9):3573-3585.

[88] Cool Energy Inc,. www.coolenergyinc.com/ Accessed 2013-04-25

[89] The Engineering Toolbox. Water - Thermal properties. Available at: www.engineeringtoolbox.com/water-thermal-properties-d_162.html. Accessed 2013-08-16.

[90] Pipeflow calculations. Flue gases properties table - density, viscosity. Avaliable at: www.pipeflowcalculations.com/tables/flue-gas.php. Accessed 2013-04-02.

[91] Asp B., Wiklund M., Dahl J. Utilisation of excess energy from the steel industry for electricity production: An effective utilisation of resources for electricity production. (Användning av stålindustrins restenergier för elproduktion: Ett effektivt resursutnyttjande för elproduktion) Report no. JK 98400. Stockholm, Sweden: Jernkontoret; 2008 [in Swedish]. [92] Pernecker G. Uhlig S. Low-enthalpy power generation with ORC-turbogenerator, the Altheim project, upper Austria. GHC Bulletin; 2002. Available at: http://geoheat.oit.edu/bulletin/bull23-1/art6.pdf

[93] Ammar Y., Joyce S., Norman R., Wang Y., Roskilly A.P. Low grade thermal energy sources and uses from the process industry in the UK. Applied Energy 2012;89 (1):3-20. 